\title{
Food security and family farming
}

\author{
Gustavo Gordillo de Anda
}

$\mathrm{T}$

his paper stems from the debate on food security that has been under way since the World Food Summit of 1996. It discusses the viability of a type of programmatic proposal deriving from the Rome Declaration and Plan of Action signed by the Governments of 148 countries, and it suggests that the implementation of the Plan of Action requires the establishment of a structural link between the population affected by food insecurity -usually unable to make its views known or exert pressure- and the various authorities responsible for initiating public action. The central hypothesis of this paper is that this structural link can be centred upon family farmers. It argues that food security, underpinned by the right to food, is a territorial expression of civic rights. 


\section{I \\ Food security: new ideas and new practices}

Although we now know that the world produces far more food than is required to meet the needs of its inhabitants, almost 800 million human beings, or one in seven, suffer from hunger (FAO, 2002a). The answer to overcoming this scourge lies not so much in increasing farm output in developing countries, as was formerly believed, as in generating work and income opportunities and in increasing the scope for marketing the agricultural products produced by the population of these countries.

The last 50 years in family farming have been marked by a combination of: rising prices for farm inputs and equipment, cutbacks in State subsidies and protection systems, and a dramatic decline in market prices for agricultural products.

This decline has been due to transformations in telecommunications and information technologies, the green revolution, and changes in biotechnology. At present, however, the main cause seems to lie in the production and export subsidy policies applied by developed countries, particularly those of the Organisation for Economic Co-operation and Development (OECD). A study by the United States Department of Agriculture (Burfisher, 2001) found that the tariffs and subsidies of developed countries depressed agricultural prices by up to $12 \%$ and were the cause of almost $80 \%$ of distortions in world trade.

Taken together, the distortion of the export capacity of developing countries and the fall in international farm prices seem to be holding back the development of agriculture in these countries to a very marked degree (Rello and Trápaga, 2001).

Nonetheless, Burfisher (2001) argues that abolition of tariffs and production and export subsidies in developed countries would not in itself be enough to remove the distortions that affect the exporting capacity of developing countries. This measure would

$\square$ The information and views in this article are the author's alone and do not necessarily coincide with those of FAO. The author is grateful to Hernán Gómez, Carlos Icaza, Paul Lewin and Rodrigo Paillacar for their comments and assistance with the preliminary editing of this article. need to be combined with others: improvements in the competitiveness of the agricultural economy in developing countries (particularly where small farmers are concerned), chiefly through investment in infrastructure and human capital formation, together with institution-building and, no less importantly, steps to reduce the high levels of social inequality, poverty and malnutrition that afflict them.

\section{The situation in Latin America and the Caribbean}

As noted above, in the short term the issue of world food security is, strictly speaking, not a technical one. The problem is that the means of production required to meet food demand are lacking, and that the neediest groups in rural and urban areas have insufficient purchasing power (FAO, 2000). In Latin America and the Caribbean, almost 54 million people are suffering from hunger and malnutrition. Instead of falling, this number has risen in some subregions, the situation in Central America and the Caribbean being of particular concern. Furthermore, some 211 million people in the region are poor, a rise of 11 million since 1990, and 89 million of these live in extreme poverty. The highest incidence of poverty (ECLAC, 2002) is in the countryside, where almost $54 \%$ of the population are below the poverty line and $31 \%$ are below the indigence line, i.e., their income is too low to meet their basic food requirements.

The problems of food insecurity and poverty are aggravated by the inequality of income distribution. In most of the region's countries the richest $10 \%$ of households receive more than $30 \%$ of all income and, in almost all of them, the percentage of total income received by the poorest $40 \%$ of households ranges from $9 \%$ to $15 \%$ (ECLAC, 2002). Because local wages are low, some countries have achieved sufficient levels of production and productivity to become exporters of certain agricultural products and increase their incomes. Nonetheless, the fact is that extreme poverty and chronic undernutrition have not 
disappeared and have even increased in many countries (FAO, 2002a).

To sum up, the agricultural transformations of the last half-century have taken the region's agriculture towards two extremes: at one extreme there is a modern, profitable and mechanized agriculture that uses agrochemicals and high-yield varieties, while at the other, there is a subsistence agriculture with all its poverty, exclusion and hunger (FAO, 2000).

\section{FAO and the Special Programme for Food Security}

With the goals of the World Food Summit in mind, the Food and Agriculture Organization of the United Nations (FAO) has launched the Special Programme for Food Security (SPFs). The Programme consists of measures to improve a country's food security and aims to be something more than a pilot project, as the idea is to propose and develop national food security policies in countries requesting this. As originally conceived, it set out from the premise that viable technologies were available which, if applied properly in the countries worst affected by problems of food security, could increase agricultural productivity and food output. The original approach was too heavily oriented towards food supply and did not consider the role of institutions and actors in the results that would ensue.

Current trends in the economic, political and social dimensions of this issue ${ }^{1}$ have led to a new conception of food security, and hence to the need for FAO to refocus its programmes in this area. Evaluations of the SPFs have highlighted the following (FAO, 2002c):

i) "When the sPFs started it had what the Evaluation Team regards as a rigid and inflexible design. It also required that it initially be implemented in those areas where there was the potential for rapidly increasing production. These areas were characterised as being where there were irrigation possibilities. It was envisioned that the production

\footnotetext{
${ }^{1}$ Including lower international prices; high levels of poverty, hunger, undernutrition and inequity; heterogeneity in the asset endowment of family farmers; segmentation of labour markets; low investment by rural families; information asymmetry in markets; inadequacy and misallocation of public goods in the rural sector; duality of the rural sector, with the coexistence of competitive and subsistence farming; lack of rural infrastructure; lack of institutional capabilities; limited response capabilities of research and development systems, and the existence of a digital divide between town and countryside.
}

focus would help solve food security problems both at the household and national levels. It soon became apparent that the early 'micro' oriented production focus was insufficient to ensure progress in solving the food security problem and that 'meso' and 'macro' type issues were important in enabling production increases to occur, and in ensuring benefits accrue to the producers."

ii) As a result, "the sites selected for SPFs activities in the case study countries, have in general been of relatively high productivity, compared with the more marginal areas where the degree of malnourishment in rural areas is higher but the potential for increases in agricultural productivity are lower. Thus, although in the opinion of the Evaluation Team the areas selected for SPFS activities are likely to be the best as far as potentially improving national food security is concerned, in terms of improving individual household food security the impact of SPFs type activities was likely to have been higher in the marginal areas."

iii) "Success of the SPFs type of approach is very dependent on the strength of the institutional structures, including extension, credit, input distribution and product marketing systems. Where there are deficiencies in this, it is very unlikely that a two to three year period will be sufficient to demonstrate impact."

iv) "Systematic evidence of the degree of adoption/ uptake of the technologies demonstrated by the SPFS was not available, partly because the SPFS has not generally collected such information and partly because many of the projects are ongoing, or have only recently ended. [...] there was relatively little evidence of continued use of technologies after project demonstrations, or of adoption by farmers who had had no association with SPFS."

v) "The SPFs has made extensive use of subsidies to encourage technology adoption. This has taken two forms: providing inputs free to farmers and/ or giving inputs at subsidised rates. This needs to be re-examined particularly since it does not bode well for the sustainability of the technologies after direct SPFS support to initiatives ceases."

vi) "In general, to date, the impact of SPFS on national policies relating to food security, and on the donor community in terms of strategies for enhancing food security in Low Income Food Deficit 
Countries (LIFDCs) and resource mobilization for SPFS follow-up, has been limited."2

The SPFs has also undergone adaptations to suit it to the specific conditions prevailing in Latin America and the Caribbean: i) it is financed out of the publicsector resources of the countries themselves; ii) it operates in countries at an intermediate level of development ${ }^{3}$ and not only in those with low incomes and a food deficit; iii) it is multisectoral; iv) coverage is national from the outset, and v) it is of long duration. Again, some phenomena specific to the region, or to certain areas within it, affect food security. These include institutional weakness; problems with consolidating decentralization; high vulnerability to natural disasters and an urgent need to improve risk management (by means of early warning systems, for instance), the high social and economic risk entailed by overdependence on some commodity whose price can suddenly fall sharply, such as coffee; and the various tensions caused by trade integration processes (such as the process whose objective is the Free Trade Area of the Americas) and treaties.

With this revised approach to food security, conceived as a right and having the central objective of improving family access to food, the unit of reference ceases to be the farm and becomes the rural family instead. The result is a comprehensive approach that focuses more on people's welfare than on raising agricultural output or productivity.

\footnotetext{
2 The evaluation was conducted by a representative team of nine senior external consultants with the operational support of the FAO Evaluation Service. The Evaluation Team visited the regional offices of FAO and 12 countries in the developing regions where the SPFS has been applied (Bangladesh, Bolivia, Cambodia, China, Ecuador, Eritrea, Haiti, Mauritania, Niger, Senegal, Tanzania and Zambia). The Team selected the countries to be visited from a list of 18 countries representing all the developing regions drawn up by FAO. These were countries where fieldwork had begun at least three years before and had covered at least three of the four components of the SPFS. The selection criteria made it certain that the evaluation work of the Team would be based on considerable experience with SPFS implementation.

${ }^{3}$ Brazil, the Dominican Republic, Mexico and Venezuela.
}

Thus, food security is no longer treated merely as an exercise in technology transfer, but has been established as a civic right. This raises a crucial question: what segment of the population are these food security programmes aimed at?

Any food security policy whose central thrust is the right to food obviously needs a clear definition of the population at risk, such as landless peasants, small farmers, rural families, indigenous populations, women, children and settlers in peri-urban areas. Nonetheless, targeting the population at risk does not in itself guarantee that this population will be incorporated into food security programmes and projects. There needs to be a structural link between this population, which generally has no way of making its views heard or exerting pressure, and the various authorities responsible for initiating public action. Without such a structural link, the gap tends to be filled by political patronage, or the measures taken do not reach the population at risk but are captured by other sectors with greater bargaining power. The present article suggests that this structural link can be made with family farmers, both because of their dynamism and because of the enormous presence that ensues from the multifunctional character of their production activities.

The key question, after presenting the type of programmatic proposal stemming from this expanded version of food security programmes, is how politically and economically viable this type of proposal can be in Latin America. A basic strategy to pursue new forms of public intervention in the countryside clearly requires building a consensus in relation to the objectives, terms and costs of the main rural advancement policies. These agreements then need to be converted into legal reforms to ensure that commitments will be honoured and to guarantee policy continuity. To be able to gauge the viability of this proposal, it is now necessary to examine the conditions under which consensus could be arrived at. I shall begin with some reflections on recent social movements in the countryside and on the nature of the structural reforms of the 1990s, which have been one of the main causes of these movements, before laying out a set of specific proposals based on the concept of the right to food. 
II

\section{Social mobilization as a means of generating institutions}

\section{Some thoughts about the meaning of rural movements}

The profound changes that Latin America is undergoing make social protests and unrest inevitable. From the standpoint adopted in this paper, social protests can be seen not just as a means of changing the correlation of forces and increasing the bargaining power of certain social actors, but also as a force for productive restructuring and institutional innovation in societies that are quite unequal, fragmented and fragile from an institutional point of view. This approach yields a specific dilemma: how can social conflicts be solved in this sphere without irreversible confrontation between social actors? And how can conflict resolution processes and efforts be guided so that institutional agreements are strengthened, or new ones generated?

Social movements arise as a form of positioning in response to change, when social actors and organizations feel affected, or potentially affected, by the appearance of new institutional arrangements or the abandonment of old ones. It must be stressed here that any attempt to classify rural movements into exclusive categories comes up against the frequent overlaps between different demands and types of struggle, owing to the ambivalent and changing nature of rural actors in their relationship with society at large and with the State and market in particular.

Social mobilization can be channelled through agreements based on an ethics of responsibility that makes it possible to experiment with innovative institutional arrangements. Obviously, not all social movements result in institutional innovation, since they entail a high risk of disruption, spurred in Latin America by two factors whose conjunction has helped shape the current situation in the region: structural social inequality, which is of very long standing and does not date only from the current period of reforms, and extremely rapid change, carried through hastily and clumsily, which is undermining social cohesion and cultural certainties.

After almost two decades of structural reform, it should be clear that any society is a highly dynamic human construction where conflicts and tensions are not the exception, but the rule. It is even more obvious that these conflicts come to the surface at times like the present, when societies are in the grip of profound changes of both global and local origin. It is precisely at such times that it is essential to establish a strong link between a sound legal framework and social movements, to assist in the transition from social protest -which is spontaneous and disruptive by its very nature - to collective civic action. This transition from spontaneity to rationality in collective action is not just a change from the short term to the long in the outlook of social actors. It is also the basis for mutual agreements between State organs and social actors. More importantly still, this bridge between legality and spontaneous mobilization can ensure that social protests and conflicts are transformed into innovations, experiments and solutions, both in the sphere of the actual rules used to channel conflicts and in the spheres that gave rise to mobilization. This bridge-building process is what I call social mobilization as a means of generating institutions.

What has happened recently in many of the social movements that have arisen in the region has been a spontaneous, violent upheaval in certain sectors of society, followed by direct repression and short-termist, ad hoc solutions to contain them. In many cases, protests have led to the resignation of democratically elected Presidents: De la Rúa in Argentina, Fujimori in Peru and, recently, Sánchez de Losada in Bolivia. ${ }^{4}$

The message of recent rural movements seems fairly clear, even though these have differed from one another and varied in intensity. They have not only been insisting on more equal opportunities, but rejecting a view of redistributive justice centred exclusively on corporate agreements. Involvement in making and implementing decisions is another demand. The unifying principle is an expanded vision of popular sovereignty, in which the principle of justice is associated with the principle of democracy. The freedom

\footnotetext{
${ }^{4}$ What Luis Maira has called "the revocation by society of presidential mandates".
} 
being fought for involves equal participation at the various levels of society and the State.

Faced with these demands, the promise held out by reforms aiming at economic and political liberalization in Latin America was the formal abolition of policies with an anti-agricultural bias; however, appreciating exchange rates, the systematic decline of international agricultural prices and tight credit have cancelled out many of the advantages that this model offered to the farm sector. Consequently, public policies for the countryside have been exploited by a small oligarchy that has skewed their content and implementation in their own favour, or subordinated them to the interests of the most powerful urban actors, so that they have tended to become appendages of a development strategy.

\section{The rage to conclude: ${ }^{5}$ the pace of reform}

Developments in the rural sector of Latin America in recent years can be described as a long transition towards institutionalized forms of democratic governance.

The structural reforms of recent decades sought economic stabilization as a means towards competitiveness. The main changes implemented were: deregulation, the modernization of bureaucracies and the privatization of the main State-owned firms. ${ }^{6}$

These reforms gave way to a period of institutional crisis in the rural sector, marked by four factors: i) an institutional vacuum, as economic liberalization was affected by the unsuccessful or incomplete transfer of operating functions from the State to the private sector in particular areas, such as agricultural extension, the marketing of agricultural products and formal credit; ${ }^{7}$

\footnotetext{
5 This is an allusion to Flaubert's well-known phrase, quoted by Albert Hirschman in his pivotal work on the unfinished drive for reform in Latin America in the second half of the last century, entitled Journeys towards Progress (Hirschman, 1963).

${ }^{6}$ An initial phase sought to achieve economic stabilization by adjusting macroeconomic prices (exchange rate, interest rate and inflation control) to correct biases against certain sectors and encourage noninflationary economic growth. A second phase addressed market failures through "structural change"; the main measures taken (trade liberalization, privatization and deregulation) sought to make market financing better and more transparent in order to solve the problems of asymmetrical information. A third phase, which is barely beginning in many of the region's countries, seeks to address failures of cooperation between social actors (see Gordillo, 1999).

7 The institutional vacuums left by the withdrawal of State action in certain areas (in the absence of any deliberate policy to create new institutional arrangements) have been filled haphazardly by parallel markets and informal arrangements. The economic and social cost has been high, especially when these processes are analysed over the longer term.
}

ii) a mismatch between the desire and ability of rural institutions to renew themselves; iii) resistance to change and reforms, manifested in the absence of mechanisms for dialogue and coordination, and iv) a lack of coordination between institutional development in the countryside and changes in the rest of the economy and society.

The combination of these factors has often resulted in selective modernization in particular sectors or regions, based on simplistic economic criteria classifying regions, and even individuals, as "viable" and "unviable". In fact, this has been the surest way of intensifying productive and social imbalances in the countryside.

Meanwhile, the efficiency factor in institutional change cannot be separated from the distributive factors involved in institutional reforms of all kinds, which involve changes in power and political processes.

Under present circumstances, the macroeconomic environment of the region's countries cannot by itself offer any real, lasting alternative to displaced rural actors or areas. Thus, the absence of active development policies inevitably results in an institutional vacuum and social exclusion.

It makes no sense, therefore, to promote flexibility, transparency and participation without recognizing the crucial importance of public-sector intervention. At the same time, it is surely vital to bring all the many differentiated strategies and the social actors embodying them into a broad dialogue whose outcome is inclusiveness: the cornerstone of any effective rural reform strategy is the inclusion of all social actors in whatever institutional agreements are being worked towards, i.e., the incorporation of rural workers, family farming, indigenous populations, women, commercial farmers, agro-industrialists, investors, and other increasingly important actors such as supermarket chains. ${ }^{8}$

But this dialogue needs precise rules and a structure of incentives to ensure the inclusion of all within the framework of an ethics of responsibility.

In this context, what I understand by institutional reconstruction is a deliberate process undertaken by sectors representing majority opinion in the State and society in response to an extreme situation caused by

\footnotetext{
${ }^{8}$ Sectoral policies are no longer enough to safeguard the interests of most families working in agriculture alone. What is needed now is convergence with territorial policies that look beyond agriculture to reduce inequalities and exploit natural resources rationally.
} 
a combination of social fragmentation and institutional weakness and requiring a mutual pledging of rights and obligations. These pledges are what I call pactos de garantías, institutional constructs specific to these situations that cover all three institutional spheres: operational, governmental and constitutional. Because the pledge cannot exist in a vacuum, the role of social actors and movements has to be built into this institutional scaffolding. A pacto de garantías has a single purpose: to create a basis upon which the differences that are inevitable in pluralist societies can be resolved. The idea is not to attribute a mythical value to consensus-building, but to appreciate that there is no substitute for it when it comes to modulating the pace of change. This process of institutional reconstruction, of which the pacto de garantias is the expression, can be driven by social movements, by particular policies, and by a good structure of enforcement institutions.

Institutional reconstruction seeks to address problems of social cohesion. This has to be the central objective of public policies in the rural sector, and it needs to have the unquestionable social legitimacy that can only be conferred by the participation of rural actors in the design and implementation of such policies.

Rural actors are interrelated with institutional change: they are active agents ${ }^{9}$ and at the same time they may be among those affected by change. Not all actors participate in institutional change in the same way or at the same time, but they all feel its repercussions, albeit to differing degrees. Institutional reconstruction in the countryside may mean, of course, that particular agents find that their existence is imperilled, ${ }^{10}$ or that they have to adopt a different collective identity. The

\footnotetext{
9 They participate in or promote institutional change, for example, by mobilizing; or, where local forums or councils exist (i.e., where social interaction is institutionalized), by participating in discussions or decision-making.
}

vital thing, though, is the pace at which these changes are to be implemented.

As regards the political economy of reforms, of their adoption and implementation, ${ }^{11}$ an important consequence of the approach I suggest here is that consensus-building is the only way of setting a "pace of change" that allows the inevitable instability to be managed. The idea is to map out a route towards change that reflects consensus, directionality and certainty in agricultural and rural policies, with a view to creating security and avoiding the risks of discretionary actions and authoritarian agricultural and rural policies. These elements establish a vital basis that enables future institutional development to acquire the desired characteristics of autonomy, inclusiveness and effective subsidiary action by the State.

It is necessary, then, to visualize an institutional framework that takes in not only the different forms of State intervention or the organization of State agencies, but also the whole range of informal rules and conventions, and indeed the ethical and moral norms of conduct that are part of social interaction. In this broader view, the main role of institutional development is to increase efficiency and reduce uncertainty by designing a stable (although not immutable) structure conducive to economic and social interaction. This structure of opportunities and incentives is the determining factor in economic performance.

This overarching institutional framework, emerging from these bottom-up and top-down changes, calls for a series of reflections about the right to food as a territorial expression of civic rights, and about decentralization in the framework of a regional development policy.

\footnotetext{
${ }^{10}$ A local party chief, or an inefficient or incompetent public-sector actor, may be deposed or taken to task as a result of institutional change.

${ }^{11}$ Probably one of the most important works dealing with the pace of change is Karl Polanyi's book The Great Transformation: The Political and Economic Origins of Our Time (Polanyi, 1957).
} 


\section{III}

\section{Decentralization and the right to food}

\section{Progress with the human rights-based approach to development}

In seeking to design public policies that enhance the competitiveness of family farmers and to establish fair rules that give their products access to international markets, it is necessary to get past the idea that the development of peoples or individuals and the struggle against hunger are acts of kindness on the part of authority, and to recognize once and for all that they are in fact part of any State's obligation to guarantee the exercise of universal human rights by its citizens.

Although human rights have traditionally been associated in the main with the civil and political sphere, it is worth emphasizing that equal status was accorded by the 1948 Universal Declaration of Human Rights to various economic, social and cultural rights that became the basis for the 1976 International Pact on Economic, Social and Cultural Rights. This Pact laid down the obligation for States to guarantee the right to food, which is deemed to have been fulfilled when people have physical and financial access at all times to adequate food and to the means of obtaining it.

This is often wrongly interpreted as meaning that the State is obliged to feed its population, when what the right to food actually means is that the State, and particularly the government, has to respect and protect people's right to feed themselves. To clear up any doubts, in 1999 the Committee on Economic, Social and Cultural Rights laid down the scope of State obligations in this area in its General Comment No. $12 .{ }^{12}$ These can be classified into three levels:

i) The obligation to respect. This lays down the limits on the exercise of State power. It means that the government must not interfere with people's means of subsistence, or obstruct their access to food, or deprive them arbitrarily of their right to this.

ii) The obligation to protect. This means that the government has to pass laws to prevent powerful individuals or organizations from infringing people's right to food, and must appoint

\footnotetext{
${ }^{12}$ See United Nations, Committee on Economic, Social and Cultu-
} ral Rights (1999). authorities to investigate and provide effective recourse if this right is violated.

iii) Obligation to facilitate and if necessary to provide. This means that the government has to take pro-active measures to identify vulnerable groups and apply policies so that they have access to adequate food, facilitating their ability to feed themselves. The obligation to provide goes further than the obligation to facilitate, but only arises when people's food security is imperilled for reasons beyond their control. As a last recourse, it is considered that the need may arise to provide direct assistance through protection networks.

These three levels give a better idea of the scope of State obligations when it comes to guaranteeing the right to food, and provide an ethical, political and legal frame of reference. Basing public-sector rural development policies on the exercise of human rights, particularly the right to food, removes these policies from the realm of charity or welfare and makes them less vulnerable to the vagaries of politics. They become legally enforceable, subject to scrutiny and, where appropriate, arbitration.

Although the right to food has been recognized in different international instruments, the concern to have it treated as such in rural development and antihunger policies only began to gain strength in the 1990s, as part of the debate about third-generation rights. The 1996 World Food Summit took up this debate and included among its commitments an undertaking to clarify the substance of the right to adequate food and freedom from hunger, and to pay particular attention to its application.

Establishing a better definition of the right to food, with a view to creating concrete instruments so that it can be better applied, has begun to be a major concern of civil society and some of the world's governments. It is worth giving a mention here to the proposal to create an international code of conduct for the right to food. Although this code would essentially be a political document rather than a legal one, its approval would establish a series of national and international obligations and responsibilities, so that it would make a valuable contribution to the construction of a new system of world institutions based on the right to food, 
which would strongly influence the design of development policies.

\section{Decentralization and regional disparities}

Despite almost universal acceptance of the merits claimed for decentralizing reforms, and although these have spread very widely in the region, there is still only a fairly limited scientific understanding of the institutional arrangements needed to underpin effective decentralized administration. Furthermore, a growing body of empirical evidence suggests that decentralization, be it administrative, fiscal or political, or a combination of these, can facilitate the emergence of collective action institutions but does not automatically yield the advantages envisioned by its supporters. It is necessary to be wary, therefore, of the simplistic notion that decentralization alone resolves some of the most pressing problems in the countryside. As in any institution-building process, what is needed is the right mixture of national and local action. While decentralization has generally been regarded as a mechanism that strengthens social participation in the design and implementation of public policies, to avoid isolated measures that are likely to dislocate government action it may be essential to place decentralization within the framework of a regional development policy.

More recently, as a result of globalization itself, there has been a growing need for different measures designed specifically to reduce socio-economic disparities between territories and cities and to optimize their development opportunities. These measures are now known as territorial development policies (or more simply, territorial policy). These policies are not aimed just at the most disadvantaged territories, but at all of them, from the richest to the poorest. Their objective is not to attract investments to marginalized territories by offering subsidies and other benefits to investors, but to ensure that they are all in a position to maximize their endogenous development opportunities. To achieve this goal, it is essential to capitalize on the advantages of each, the pull effect of their towns and cities and the creation of assets. Of course, this does not mean discontinuing assistance and compensation for poorer territories, which need to benefit from "financial equalization", but generating the right kinds of bonds and ties between those that progress more rapidly and those that do not. Furthermore, infrastructure needs to be provided for all to ensure a minimum level of accessibility. Since this depends on the individual characteristics of each, infrastructure policies need to be based on a typology of territories (Schejtman and Berdegué, 2003).

Territorial approaches are by definition multisectoral and certainly need to help build bridges among different development objectives and reconcile them. Furthermore, these approaches offer two additional benefits: they trigger a greater awareness of the nature and urgency of problems, and they offer solutions that are more compatible with local constraints, be these institutional, financial or environmental. Thus, when the heterogeneity of the rural sector is overlooked and the countryside is identified with agriculture, ${ }^{13}$ the scope for improving competitiveness and mitigating rural poverty is reduced because factors which dynamize agriculture itself and which may derive from stronger links with nearby urban centres are not considered. The bulk of activities are thus targeted on farming, whereas the diagnosis ought to include in its understanding of the countryside those urban centres with which small producers are directly linked.

Examining demand in these urban centres and the territorial sphere of small farmers can provide clues as to needs that are going unmet, or that are being met but with high transaction costs. Simple measures can be taken to remedy this and thereby help to raise the competitiveness of some of these producers or, in the case of families with little or no land, to improve their living and working conditions by lowering their transaction costs across a range of activities. If projects are to be key components in rural development strategies, then, their design needs to take account of the territory involved, the economic sectors acted upon, the social structure of the territory and the duration of processes, and to provide for an institutional structure that ensures their sustainability over time.

Territorial development policies seek to raise a territory's value-added, achieve significant growth in the rural economy and, in particular, enhance the social capital of the territory rather than promoting the development of any one economic activity in particular (Abramovay, 1999). To this end, territorial development takes a view of production chains that goes beyond broader agriculture ${ }^{14}$ to the linkages between the various sectors and actors in a given chain.

\footnotetext{
13 Thus it fails to take account of the links between the countryside and urban centres, or the importance of rural non-farm employment, which is expanding and influencing rural performance to an ever greater degree.

${ }^{14}$ Broader agriculture means the different linkages that agriculture has with activities of other types generated around it. These activities include, among others, demand for inputs, instruments and machinery, post-harvest or processing activities applied to agricultural products, and marketing.
} 


\section{IV}

\section{Family farming}

\section{A mobilizing factor: family farmers}

The experience of the last decade, whether in relation to social mobilization or productive effort and institutional innovations, tells us that the most dynamic segment in the countryside are family farmers, characterized in the region by the heterogeneity of their resource endowment and assets, i.e., their natural, physical, financial, human and social capital (de Janvry and Sadoulet, 2001a). This inequality of conditions, along with market failures, is one of the causes of rural poverty.

In a simplification that does, however, reflect the main characteristics of the Latin American and Caribbean countryside, family farmers can be classified into two major groups by asset level. The first group comprises peasants whose territorial resources are so small that they live essentially from wage labour, in agriculture or elsewhere, supplementing their income by farming. The second comprises family farmers who own varying quantities of land and obtain much of their income from crop growing, supplementing this by selling their labour (ECLAC, 1999).

Workers in both groups are compelled to have recourse to non-agricultural forms of rural employment that supply a large part of rural households' income and act as a substitute for land as a source of earnings. In a compilation study ${ }^{15}$ put together by de Janvry and Sadoulet (2001a) it was found that in the Mexican ejido (common land), for example, rural non-farm employment accounted for $55 \%$ of total income (de Janvry and Sadoulet, 2001b), while the figure was $61 \%$ in Nicaragua and Panama (Davis, Carletto and Sil, 1997; World Bank, 1998), 67\% and 60\% in Chile and El Salvador, respectively (López and Valdés, 1997), and $86 \%$ in Ecuador (Lanjouw, 1996). It should be pointed out, however, that these methods of supplementing income are not enough to rescue family farmers from the poverty in which they live. Owing to institutional and market failures, moreover, families have recently come to depend more and more on rural

\footnotetext{
15 Based on a pioneering study of rural families in the reformed
} sector in Mexico (Gordillo, de Janvry and Sadoulet, 2000). non-farm income (especially remittances) and on investment in animals and grains as a source of savings and liquidity for emergencies.

The transition from protected agriculture to agriculture with a broad basis of growth and competitiveness will require the currently low levels of investment prevailing among family farmers to increase, and this will take a great deal of time. The goal of improving access to food is closely linked to the need to improve the competitiveness of family farmers, on a territorial basis and with a focus on families and family incomes.

But if we follow Easterly (2002), we can say that the competitiveness of small farmers is also related to the degree of inequity in a country, since inequality hinders development. Sokoloff and Engerman (2002) ${ }^{16}$ suggest that asset endowment determines inequity, which in turn is the root cause of poor institutions (undemocratic and unstable), poor redistribution policies, low investment in human capital, and underdevelopment.

Strengthening the role of family farmers means improving their competitiveness in markets for land, products, labour and financing, which requires them to have the information needed to operate in these markets on advantageous terms. The theory, according to Escobal (2002), is that there are four types of failures in institutions that affect the competitiveness of rural families: i) information asymmetry, ii) the availability and allocation of public goods, iii) externalities and iv) the problems of poverty and equity.

Information asymmetry reduces access to markets that are necessary for small producers to be competitive. There are problems with access to information on rural credit mechanisms, both on the side of rural families and on the side of the banks themselves, and the same is true of access to land ownership. It is also very important for grass-roots organizations ${ }^{17}$ to be provided with information on local development programmes and policies,

16 Cited by Easterly (2002).

17 These being groups with common interests, such as women's groups, saving clubs, cooperatives, producers' or irrigation associations, etc. 
mechanisms for applying for project financing funds and procedures for interacting with the government and market (Alkire and others, 2001).

Misallocation and scarcity of public goods hinder the development of rural sectors. Geographical dispersion and lower population densities are directly related to inadequate infrastructure and limited access to public services, so that investment in these sectors is considered risky and costly. Furthermore, restricted access to public goods and services undermines local input and product markets, and this combines with high transaction costs to restrict the ability of rural families to save. It is possible that local efforts towards collective organization may enable progress to be made in this area, particularly in the case of small-scale, lowcomplexity $^{18}$ goods and services that require local cooperation, be they communal (common pastureland, water for irrigation and so on) or public (local infrastructure).

The problems of poverty and inequality create a vicious circle. ${ }^{19}$ When market institutions do not resolve these problems, the combined institutional arrangements of public-sector bodies and civil society organizations have to underpin the equity and sustainability of policies and consensus between parties. For this it is necessary to improve the structure of social policy through public-sector management that is based on transparency, citizen oversight and accountability.

For all the reasons given, there is a need for policies to raise the competitiveness of rural families so that these can increase their incomes. It is essential for the productivity of the poorest to be improved, and for this improvement to involve their participation in a growing economy with fair markets. If families are able to improve their income levels, they will enjoy food security.

As a number of studies have pointed out, almost half the income received by rural families in the region comes from non-agricultural activities. Furthermore, as a logical consequence of this diversification in rural economies, capital investment processes in the rural sector are very heterogeneous. This being so, policies

\footnotetext{
${ }^{18}$ Low complexity in this context refers to the homogeneity of actors and their interests.

${ }^{19}$ Lynn Karl (2002) has explained this vicious circle as a situation where poverty and high levels of inequality perpetuate each other and in turn restrain economic growth. This situation makes it considerably harder to deal with the problems that derive from poverty and inequity.
}

to raise the competitiveness of rural families need to take account of the heterogeneity and diversification of rural markets ${ }^{20}$ and aim at territorial rather than sectoral development.

In agriculture, heterogeneity entails the coexistence of two sectors, each of which has internal differences as well. One of these two sectors is modern, businesslike, capital- and technology- intensive and chiefly export-oriented. The other is intensive in lowproductivity labour, displays major deficiencies and segmentations, is underendowed with assets and has very low investment, all of which makes it hard to attain the efficiency, competitiveness, modernization and profitability that a sectoral policy might aim at. Experience has shown that most rural families in a situation of food risk depend on this type of agriculture. The modern agricultural sector, meanwhile, instead of creating strong demand for labour has displaced people and absorbed most agricultural aid owing to its greater bargaining and political power. This has intensified the concentration of land and productive resources and widened the gap between commercial agriculture and family farming.

Family farmers, therefore, face internal and external obstacles to improving their competitiveness. One way of confronting these is to try to expand their social and human capital by participating more in organizations that enable them to influence the design and application of development and marketing policies, and also by improving their production techniques. In turn, governments should work to improve the functioning and reliability of product, land, labour and financing markets and to increase producer confidence in social security mechanisms for overcoming constraints on natural resources, markets and infrastructure. Furthermore, States should try to mitigate inequity through more democratic and stable institutions, better redistribution policies and greater investment in human capital.

\section{A programme of support for family farming}

On the basis of the foregoing, a minimum programme to support agriculture and rural development has been

\footnotetext{
20 The rural world has seen vigorous growth in service sectors not directly linked to agrifood and industrial chains, but meeting demand from human settlements in the countryside. Furthermore, construction, infrastructure and public services are featuring ever more strongly in the rural economy, reducing the share of the agricultural sector.
} 
stylized, ${ }^{21}$ combining different development policy measures to improve the functioning of rural markets. The starting point was the observation that the dispersion of instruments harmed rural actors (especially family farmers), raised transaction costs, encouraged corruption and fomented disputes between State bureaucracies, leading to duplication of effort. It can never be stressed too strongly that what matters even more than the amount of public resources going to the countryside is the way these are channelled.

This minimum programme needs to contain certain elements to underpin a basic strategy for new forms of public support in the countryside. Its objectives are as follows:

i) To increase the competitiveness of what is produced by rural inhabitants affected by the region's economic changes and structural reforms by means of direct, temporary, selective support that equips them to compete in new areas of specialization, fully respecting the need to conserve natural resources. A rural incomes policy whose continuity is guaranteed by law and periodically reviewed ${ }^{22}$ can provide the core of a unified support programme for family farming.

ii) To promote voluntary, self-sustaining partnership initiatives among the rural groups affected, so that these can form organizations capable of sustaining the initial achievements of such income support programmes over time. iii) To provide direct assistance and services to households in disadvantaged areas. This direct support policy can become the starting point for a set of policy instruments which, properly designed, should help strengthen the new links between policies, producers and other economic agents.

iv) A system of rural financing that mobilizes saving in the family farming sector and emphasizes capital formation.

v) An infrastructure policy that, without neglecting certain large-scale strategic irrigation projects, aims at a considerable increase both in small-scale production infrastructure (irrigation, soil and aquifer conservation) and in commercial infrastructure (roads, warehouses, refrigeration plants and transport systems).

vi) A policy of support for innovation and technology transfer that involves universities and technology institutes in a programme of mass transfer and dissemination of skills and know-how, supported by new interactions with producers and underpinned by the premise that human capital is a key factor in competitiveness.

vii) Equitable, sustainable policies for access to the natural resources needed to sustain adequate livelihoods for the rural populations of the region, these policies to include land reforms and other land access mechanisms as appropriate.

\section{Bibliography}

Abramovay, R. (1999): Sete desafíos para desenvolvimento territorial, Fundação Lyndolpho Silva/Banco Nacional da Agricultura Familiar (BNAF), www.bnaf.org.br/palest04.htm.

Alkire, S. and others (2001): Community-driven development, PRSP Sourcebook, www.worldbank.org/poverty/strategies/ sourctoc.htm.

Burfisher, M.E. (ed.) (2001): Agricultural Policy Reform in the WTO: The Road Ahead, ERS Agricultural Economics Report, No. 802, Washington, D.C., United States Department of Agriculture.

Davis, B., C. Carletto and J. Sil (1997): Los hogares agropecuarios en Nicaragua: un análisis de tipología, Berkeley, University of California.

\footnotetext{
${ }^{21}$ In other words, a set of invariable elements has been identified, obviously requiring adaptation to the very heterogeneous character of the region's countryside and to priorities that will likewise depend on the particular context.

${ }^{22}$ One example is the Programme of Direct Support to the Countryside (PROCAMPO) in Mexico, which can provide a basis for this, particularly since the recent amendments to the Rural Capitalization Act.
}

De Janvry, A. and E. Sadoulet (2001a): La inversión en el desarrollo rural es buen negocio, in R. Echeverría (ed.), Desarrollo de las economías rurales en América Latina y el Caribe, Washington, D.C., Inter-American Development Bank (IDB). (2001b): Income strategies among rural households in Mexico: The role of off-farm activities, World Development, vol. 29, No. 3, Amsterdam, Elsevier Science.

Easterly, W. (2002): Inequality Does Cause Underdevelopment: New Evidence, Washington, D.C., Center for Global Development.

ECLAC (Economic Commission for Latin America and the Caribbean) (1999): Efectos sociales de la globalización sobre la economía campesina: reflexiones a partir de experiencias en México, Honduras y Nicaragua, LC/MEX/L.382, Mexico City, ECLAC Subregional Headquarters in Mexico.

(2002): Social Panorama of Latin America, 2001-2002, LC/ G.2183-P, Santiago, Chile, October. United Nations publication, Sales No. E.02.II.G.65.

Escobal, J. (2002): Nuevas instituciones para el desarrollo agrícola y rural en América Latina y el Caribe, CUREMIS II, Rome, Food and Agriculture Organization of the United Nations (FAO).

FAO (Food and Agriculture Organization of the United Nations) (2000): The State of Food and Agriculture, 2000, Rome. Rome. (2002a): The State of Food Insecurity in the World, 2002, 
(2002b): World Food Summit: Five Years Later, www.fao.org/ worldfoodsummmit

(2002c): Independent External Evaluation of the Special Programme for Food Security, Rome, www.fao.org/spfs/ y www.fao.org/docrep/

Gordillo, G. (1999): La ansiedad por concluir: lecciones de las reformas estructurales en América Latina. Mercado de valores, Mexico City, Nacional Financiera, October. Also available at www.rlc.fao.org/quiensom/rlc/gordillo/default.htm.

(2003): El desarrollo rural y el combate al hambre, la pobreza y la desigualdad, document presented at the Workshop "La importancia del enfoque territorial en el desarrollo rural de América Latina y el Caribe" (Milan, 20-21 March 2003), organized by the International Fund for Agricultural Development (IFAD)/Food and Agriculture Organization of the United Nations (FAO)/Inter-American Development Bank (IDB), and financed by the Government of Italy.

Gordillo, G., A. de Janvry and E. Sadoulet (2000): La segunda reforma agraria en México, Mexico City, Fondo de Cultura Económica.

Hirschman, A. (1963): Journeys toward Progress, New York, Twentieth Century Fund.

Izam, M and V. Onffroy (2000): El sector agrícola en la integración económica regional: experiencias comparadas de América Latina y la Unión Europea, Comercio internacional series, No. 8, LC/L.1419, Santiago, Chile, Economic Commission for Latin America and the Caribbean (ECLAC). United Nations publication, Sales No. S.00.II.G.91.

Karl, T.L. (2002): The Vicious Cycle of Inequality in Latin America, Working Paper, No. 2002-177, Berkeley, University of California.
Lanjouw, P. (1996): Rural Poverty and Non Agricultural Employment in Ecuador, Washington, D.C., Policy Research Department, World Bank.

López, R. and A. Valdés (1997): Rural Poverty in Latin America: Analytics, New Empirical Evidence and Policy, Washington, D.C., Technical Department, World Bank.

Polanyi, K. (1957): The Great Transformation: The Political and Economic Origins of Our Time, Boston, Beacon Press.

Rello, F. and Y. Trápaga (2001): Libre mercado y agricultura: efectos de la Ronda Uruguay en Costa Rica y México, LC/L.1668-P, Mexico City, ECLAC Subregional Headquarters in Mexico. United Nations publication, Sales No. S.01.II.G.203.

Schejtman, A. and J. Berdegué (2003): Desarrollo territorial rural, Santiago, Chile, International Network for Farming Systems Research Methodology.

Sokoloff, K. and S. Engermann (2002): Factor Endowments, Inequality, and Paths of Development among New World Economies, NBER Working Paper, No. 9259, Cambridge, Massachusetts, National Bureau of Economic Research, October.

Szekely, M. and J. Londoño (1998): Sorpresas distributivas después de una década de reformas: Latinoamérica en los noventa, Pensamiento iberoamericano, special volume, Madrid, Universidad Complutense de Madrid.

United Nations, Committee on Economic, Social and Cultural Rights (1999): Substantive issues arising in the implementarion of the International covenant on Economic, Social and Cultural Rights, General Comment 12, Twentieth Session of the Committee, Geneva 26 April.

World Bank (1998): Panama LSMS, Washington, D.C. 